\title{
Teaching Techniques Pursue Government Regulation in Education
}

\author{
Irsyad Nugraha ${ }^{1}$, \\ \{irsyadnugraha@institutpendidikan.ac.id\} \\ Institut Pendidikan Indonesia, Jl. Terusan Pahlawan No.83, Garut $44151^{1}$
}

\begin{abstract}
The education regulation in Indonesia always changes every time when the government election changes every five years as well as the president's election held. It makes many practitioners, teachers and lecturers look for suitable method and technique in their teaching in order to pursue the government objectives. Not so many education regulations can be related with English teaching and learning even though government always forces many bureaucracies for using English as their popular skill to be shown and many prerequisites applied for testing their new employments. Based on Regulation of Research, Technology, and Higher Education Minister of Indonesia number 55 of 2017 (3) about Standard of National Education, the teaching and learning process must be interactive, communicative and attractive in order to reshape students' skill for their future career. Soft skill becomes very important to prepare the students, Community and classroom interaction becomes one of the proofs that techniques can be the way to get government objectives in English Study. It was conducted in West Java Indonesia in 2018 to 150 students which were divided into 75 students get classroom technique and others for Community technique.
\end{abstract}

Keywords: Education Regulation, Government objectives and Teaching Technique

\section{Introduction}

Speaking is one of the important skills in English beside writing, reading, and listening. Speaking is the skill that the students will be judged upon most in real life situation. It is an important past of everyday interaction and most often the first impression of a person is based on their ability to speak fluently and comprehensibility(1). The mastery of speaking skill in English is a priority for many second-language or foreign language learners(2). So it can be concluded that speaking skill is the main basic for students to master their English and also the ability to express their ideas in order to produce a good communication each other.

The nonnative English students who want to speak to others sometimes face some troubles. They cannot produce their ideas, arguments or feelings communicatively. They are not confidence to speak English, they are afraid of making mistakes and sometimes they do not understand what they supposed to say. For countering these kinds of problems English teachers must be able to manage the teaching by using certain method in the teaching-learning process, so that the students will like it without boring and despair, therefore to improve the ability of students in learning language, it is better to involve psychological aspects. The teacher must give motivation to make the students feel comfortable when learning English especially in speaking. The way that must be used is by becoming a counselor for students. Students must take parts in every activity in classroom with guidance from the teacher because with a teacher's guidance, students can feel more secure, confidence, and not fear to make a mistake. 
This kind of problems also becomes government concern in having a good solution in teaching and learning process. Based on Regulation of Research, Technology, and Higher Education Minister of Indonesia number 55 of 2017 (3) about Standard of National Education, the teaching and learning process must be interactive, communicative and attractive in order to reshape students' skill for their future career. Soft skill becomes very important to prepare the students

Community language learning, also called Counseling language learning is a method which concerns with counseling technique where the teacher has a role as a counselor who helps the students in every activity of learning process if they face some difficulties to speak in English(4). Larseen Freeman states that there are no big gap between a teacher and students which usually build a comfortable atmosphere. The group will be the supportive community for the students to communicate in the target language(5), she also stated that the teacher as facilities communication in the classroom has a major responsibilities to establish situation likely to promote communication(5).

Another technique to compare from Community language learning is classroom interaction. Brown defined the classroom interaction as the communication between teachers and learners in the classroom. For example, stresses on the need for teachers to mind their talk time, teacher talk should not occupy the major proportion of a class hour; otherwise they are probably not giving students enough opportunity to talk(6). It is important for teachers to limit their talk time and let the students dominate the class. It means that students can become more responsible with their learning if they are given enough opportunity to interact with others in English. Classroom interaction in an EFL context is defined as all communication which refers not only to those exchanges involving authentic communication but to every oral exchange that occurs in the classroom, including those that arise in the course of formal drilling(7). In the field of second language acquisition, classroom interaction has long been considered important in teaching speaking. It requires in the process of second language learning, the presence of two or more students collaborate in achieving communication. Classroom interaction is necessary and useful as an educational strategy to enhance students' speaking skill(8).

\section{Experimental Methods}

\subsection{Aim of Experiments}

The aim of this research is to investigate which technique between Community Language Learning (CLL) and Classroom Interaction (CI) is better to improve students' speaking skill. The research used Quantitative Methodology with Quasi Experimental research design. The population of this research was college students in one part of city in West Java Indonesia and the sample was taken by Cluster Sampling technique. In this research the analysis was conducted by using independent t-test. The researcher tried to compare two techniques for getting the appropriate technique in speaking.

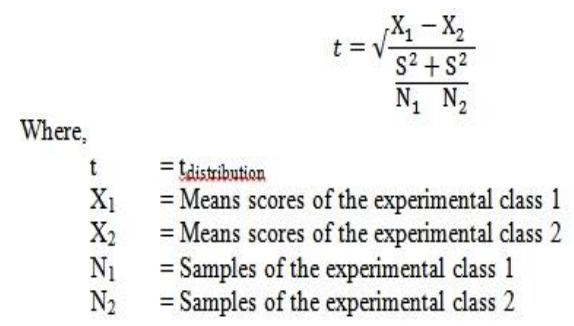

Fig.1 T-test Formula 


\subsection{Instruments}

The instruments were used in this research are teaching designs for Community language Learning (CLL) and Classroom Interaction (CI), Speaking test, and speaking rubric assessment(9).

\subsection{Community Language Learning Teaching Design}

First, the students make a group with 8 or 6 students/groups and make their seats become a circle with the teacher standing outside the circle. It makes students learn in group to make them work together in learning English. Second, students are asked to express their ideas, i.e. asking and giving opinions and the teacher translates it into English in a warm, accepting tone, in a simple language in phrases of five or six words. It will make students feel free in expressing their ideas in their native language to the target language and it exercises their step confidence in speaking. Third, the students turn to the groups and present their ideas in the foreign language. He has the counselors' aid if he mispronounces or hesitates on a word or phrase. This condition exercises him to speak in front of his friend, beside that he has counselor to have him to speak well. Fourth, record the students talk into a hand phone after they are more fluent in expressing their ideas in the foreign language. The record then played, it is use for knowing the pronunciation, vocabulary and comprehension that are used by students are correct or not.

\subsection{Classroom Interaction Teaching Design}

First, the teacher chose an interesting text. Second, the teacher gave pictures that were related with the text. Third, the teacher gave some questions to the students about the picture that was given. Fourth, the students were given time to read and comprehend the text. Fifth, the students got the explanation from teacher about generic structure and language features of the text, and students were asked to raise their hand when they understood. Sixth, the students were asked to make of groups consisted 7 members. Seventh, the students were asked to give an opinion of the text that was given. Eighth, the students were asked to speak up in front of the class about the analytical text that was given.

\subsection{Speaking Test}

The researcher tried to make the speaking test based on the issues among students in their everyday life. So the students will be easy to give their ideas because it relates to their life. The instruments of Speaking test

Choose one of the following issues. Present your opinion about issue orally.

1. Should students wear uniform at school?

2. Should mobile phone be banned at school?

3. Students are not allowed to ride motorcycle to school.

4. Smoking should be banned in our country.

5. Should Pokémon Go be banned in our country?

6. The importance of library.

7. Television must be off during study time.

8. Smoking is good for us?

9. The bad impact of bullying.

10. Gadget is bad for children.

11. Cars should be banned in the city.

12. The importance of breakfast.

13. Dangers of playing game while driving.

14. The corruptors should be given the death penalty.

15. The impact of internet in education. 


\subsection{Speaking Rubric Assessment}

The researcher also used Speaking rubric for assessing the students' result based on Suwandi(9).

\begin{tabular}{|c|c|}
\hline Rating & Description \\
\hline 6 & $\begin{array}{l}\text { Communicates competently in social and classroom settings } \\
\text { Speaks fluently } \\
\text { - Masters a variety of grammatical structures } \\
\text { - Uses extensive vocabulary but may lag behind native-speaking peers } \\
\text { - Understands classroom discussion without difficulty }\end{array}$ \\
\hline 5 & $\begin{array}{l}\text { - Speaks in social and classroom settings with sustained and connected discourse; any } \\
\text { errors do not interfere with meaning } \\
\text { - Speaks with near native fluency ; any hesitations do not interfere with } \\
\text { communication } \\
\text { - Uses a variety of structures with occasional grammatical errors } \\
\text { - Used varied vocabulary } \\
\text { - Understands simple sentences in sustained conversation; requires repetition } \\
\text { - Understand most spoken language including classroom discussion }\end{array}$ \\
\hline 4 & $\begin{array}{l}\text { - Initiates and sustains a conversation with descriptors and details; exhibit self- } \\
\text { confidence in social situations; begin to communicate in classroom settings } \\
\text { - Speaks with occasional hesitation } \\
\text { - Uses some complex sentences; applies rules of grammar but lacks control of irregular } \\
\text { forms (e.g., runned, mans, not never, more higher) } \\
\text { - Uses adequate vocabulary ; some words usage irregularities } \\
\text { - Understand classrooms discussions with repetition, rephrasing, and clarification }\end{array}$ \\
\hline 3 & $\begin{array}{l}\text { - Begins to initiate conversation; retells a story or experience; asks and responds to } \\
\text { simple questions } \\
\text { - Speaks hesitantly because of rephrasing and searching for words } \\
\text { - Uses predominantly present tense verbs; demonstrate errors of omission (leave words } \\
\text { out, word endings off } \\
\text { - Uses limited vocabulary } \\
\text { - Understands simple sentences in sustained conversation; requires repetition }\end{array}$ \\
\hline 2 & $\begin{array}{l}\text { - Begins to communicate personal and survival needs } \\
\text { - Speaks in single-word utterances and short patterns } \\
\text { - Uses functional vocabulary } \\
\text { - Understands words and phrases; requires repetitions }\end{array}$ \\
\hline 1 & $\begin{array}{l}\text { - Begins to name concrete objects } \\
\text { - Repeats words and phrases } \\
\text { - Understands little or no English }\end{array}$ \\
\hline
\end{tabular}

Fig. 2 Scoring Rubric

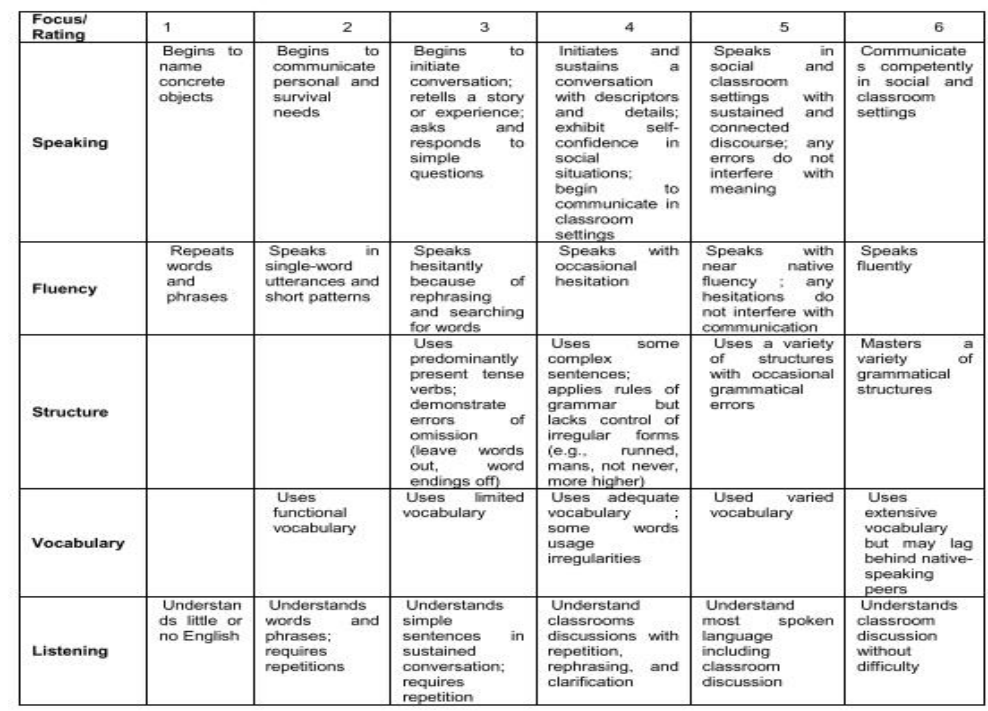

Fig.3 Analytic Scoring Rubric 


\section{Results And Discussion}

In this research there are two groups of students who take different treatment for knowing which better technique. The first group of students took Community Language Learning technique and the sample was 40 students, and for the second group took Classroom Interaction technique also used 40 students as the sample. Those samples used cluster sampling technique. The calculation that would like to be explained here was the final calculation after these both samples got pre test, treatment and post test.

Based on the data obtained, the results of pre test for sum, average, standard deviation, the highest and the lowest score are sum score 2308.33. it had average score 60.75. it had a standard deviation score 8.95. the highest score was 83.33 and the lowest score was 50.00. and for the post test sum, average , standard deviation, the highest and the lowest score are sum score 2883.33. it had average score 75.88, standard deviation score 8.29. the highest score was 91.67 and the lowest score was 50.00. Based on this result, the students who got score $>70$ were increase that pre test, the students are 33 students and the students who get scores $<70$ were 7 students. Most of students who got more than 70 was caused by active role when they followed the learning process like when the researcher stimulated them to find a new vocabulary and be able to speak good pronunciation. Beside that, they always gave a question to the researcher when they don't understand about the material or pronunciation. Meanwhile, students who got score < 70 was caused by they weren't active in learning process. They kept silent if they didn't understand and didn't ask for help.

In the pre test, the lowest score was 56 and the highest score was 83 . Whereas, in the post test, the lowest score was 60 and the highest score was 89. After that, the average of them was 67,42 in the pre test and 73,39 in the post test. Therefore, there was a different result of teaching speaking using classroom interaction strategy. As the pre test result, the students who scored 55 up to 69 were considering as high achievers. The high achievers were $71 \%$ with the total students of 23 . On the other hand, $29 \%$ students were stated as low achiever with the total students of nine. For the students who get lower than 70, they had difficulties to express their arguments. As the post result, the students who scored between 70 up to 100 were considered as high achievers. The high achievers were $58 \%$ with the total students of 21 . The high score among them was 89 . On the other hand, $42 \%$ students were stated as low achiever with the total students of 15 .

The researcher analyzed the significance value of $\mathrm{T}-$ statistic. The result of $\mathrm{T}-$ statistic can be seen from the following table:

\begin{tabular}{|lc|r|r|r|r|}
\multicolumn{1}{|c|}{ Group Statistics } \\
\hline & Class & \multicolumn{1}{c|}{$\mathrm{N}$} & Mean & Std. Deviation & $\begin{array}{c}\text { Std. Error } \\
\text { Mean }\end{array}$ \\
\hline post_test_compare & 1 & 40 & 70.95 & 8.984 & 1.421 \\
& 2 & 40 & 60.30 & 12.666 & 2.003 \\
\hline
\end{tabular}

Table 3.1: The Independent T-Test

Independent Samples Test

\begin{tabular}{|c|c|c|c|c|c|c|c|c|c|c|}
\hline & & \multicolumn{2}{|c|}{$\begin{array}{c}\text { Levene's Testfor Equality of } \\
\text { Variances }\end{array}$} & \multicolumn{7}{|c|}{ t-test for Equality of Means } \\
\hline & & \multirow[b]{2}{*}{$\mathrm{F}$} & \multirow[b]{2}{*}{ Sig. } & \multirow[b]{2}{*}{$t$} & \multirow[b]{2}{*}{ df } & \multirow[b]{2}{*}{ Sig. (2-tailed) } & \multirow[b]{2}{*}{$\begin{array}{c}\text { Mean } \\
\text { Difference }\end{array}$} & \multirow[b]{2}{*}{$\begin{array}{l}\text { Std. Error } \\
\text { Difference }\end{array}$} & \multicolumn{2}{|c|}{$\begin{array}{l}95 \% \text { Confidence Interval of the } \\
\text { Difference }\end{array}$} \\
\hline & & & & & & & & & Lower & Upper \\
\hline \multirow[t]{2}{*}{ post_test_compare } & $\begin{array}{l}\text { Equal variances } \\
\text { assumed }\end{array}$ & 10.720 & .002 & 4.338 & 78 & .000 & 10.650 & 2.455 & 5.762 & 15.538 \\
\hline & $\begin{array}{l}\text { Equal variances not } \\
\text { assumed }\end{array}$ & & & 4.338 & 70.317 & .000 & 10.650 & 2.455 & 5.753 & 15.547 \\
\hline
\end{tabular}

Table 3.2 : The Levene's Test of Independent T- Test

It reveals that the mean post test of the Community Language learning class is 70.95 ; standard deviation is 8.984; standard error mean is 1.421 . Meanwhile in Classroom Interaction technique the 
mean of post test is 60.30; standard deviation is 12.666 and standard error mean is 2.003. it shows that tobserved of the post test is 4.338 and degree of freedom (df) is in 78 . The value of $t_{\text {critic }}$ at the 0.05 level (two-tailed) with df 78 is 1.991 . From the result of the post test above, it could be concluded that Ho is rejected since $t_{\text {observed }}$ is higher that $t_{\text {critic }}(4.338>1.991)$. It means that there is significant difference mean between the Community Language Learning class and the Classroom Interaction technique class. In other words the Speaking ability of the students in Community Language Learning class is better than the Speaking ability of those in Classroom Interaction technique class. It means that the use of Community Language Learning in class A gave better improvement than the use of Classroom Interaction technique in class B.

\section{Conclusions}

Teaching Technique can't be seen as unimportant thing, in the contrary it has big impact for the successful of Government Policies. In the fact, government gives free spaces for practitioners and education experts to gain and explore what kind of technique and method to be applied toward students. Classroom and Community Technique are both techniques which have given increasing points in English studying, one of the factors is because those techniques can deliver interactive and attractive relationship between students and teachers or lecturers. So every technique can be succeeded if it has attractive and interactive atmosphere built. On the other hands our government still doesn't see this as fixed instrument to teach but try to changes it every year.

\section{References}

[1] Liao G. Improvement of Speaking Ability through Interrelated Skills. English Lang Teach ccsenet J. 2009;2, No.3:11-4.

[2] Richards JC. Teaching Listening and Speaking: From Theory to Practice. 1st Editio. Cambridge University Press New York; 2008. 1-37 p.

[3] Riset M, Tinggi DANP, Indonesia R. Menteri riset, teknologi, dan pendidikan tinggi republik indonesia. 2017;

[4] Sari NK, Syarfi M. The Use of Community language learning Method to Improve Speaking Ability of the Second Year students of SMP Muhammadiyah 2 Pekanbaru. English Lang Educ Dep Fac Teach Train Educ Riau Univ. 2015;2, No 2.

[5] Larsen-freeman D. Techniques and Principles in Language Teaching. second edi. new york: oxford university press; 2008. $106 \mathrm{p}$.

[6] Brown D. Teaching by Principles: An Interactive Approach to Language Pedagogy (2nd ed.). San Fransisco, California, USA: Longman; 2000. p. 321.

[7] Jack R. Fraenkel, Norman E. Wallen HHH. how to Design and Evaluate Research in Education. 8th Editio. New York: The McGraw-Hil Companies, Inc.; 2006. 545 p.

[8] Branch I, Branch I. the Role of Classroom Interaction on Improvement of Speaking among Iranian EFL Learners. 2015;8(January):126-35.

[9] Suwandi B. Designing speaking test. J Kopertis 6. 2009;4:183-91. 